\title{
Łódź
}

Wielokulturowa, oryginalna historia. Miasto zabytkowych pałaców, willi i XIX-wiecznych fabryk włókienniczych. Miasto wielu festiwali, wernisaży, wystaw, spektakli teatralnych. Po prostu Łódź...

Łódź leży w centrum Polski, w pobliżu skrzyżowania europejskich szlaków komunikacyjnych ze wschodu na zachód i z północy na południe. Jest trzecim co do wielkości miastem w Polsce z liczbą ludności ok. 725 tys.

\section{Polski Manchester}

Chcąc poczuć niepowtarzalny klimat miasta, należy sięgnąć do jego historii. Przez wiele wieków, mimo posiadania praw miejskich od XV wieku, Łódź była miasteczkiem rolniczym z drewnianą zabudową, polami uprawnymi i lasami. Dopiero wiek XIX przyniósł wielkie wydarzenia, które na zawsze zmieniły oblicze miasta. Głównym czynnikiem przemian był przemysł włókienniczy. Skuszeni możliwościami szybkiego zbicia fortuny, przybywali do ,ziemi obiecanej” fabrykanci i przemysłowcy z całej Europy. Geyerowie, Poznańscy, Scheiblerowie i inni zbudowali tu zespoły fabryczno-rezydencjonalne, które dziś są unikatem na skalę światową.

Prawdziwą atrakcję turystyczną stanowi kompleks Księży Młyn, który tworzą: monumentalna przędzalnia (fot. 1), domy robotnicze, budynek straży pożarnej, szpital, szkoła, folwark i willa fabrykanta.

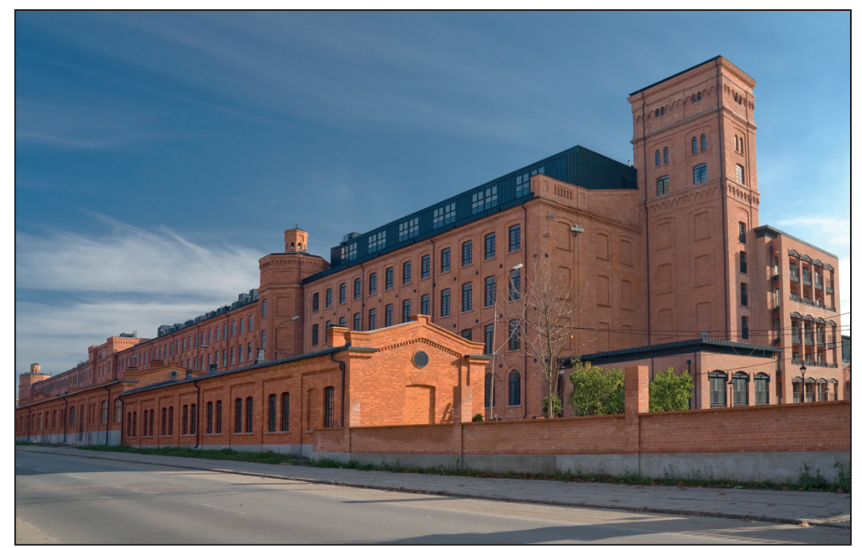

Fot. 1. Księży Młyn - przędzalnia (aut. P. Wojtyczka) 
Kolejny, zbudowany przez rodzinę Poznańskich znajduje się w północnej części miasta. Nie sposób przejść obojętnie obok budynków wzniesionych z czerwonej cegły, których architektura nawiązuje do średniowiecznych twierdz obronnych. Wielkością i różnorodnością detali zachwyca stojący obok, okazały pałac Poznańskich - największa rezydencja fabrykancka w Europie (fot. 2). $\mathrm{W}$ urządzonych $\mathrm{z}$ wielkim przepychem wnętrzach mieści się Muzeum Miasta Łodzi, a dawna fabryka pełni dziś funkcje kulturalno-handlowo-rozrywkowe (Manufaktura). Spacerując po mieście, można odnaleźć wiele przykładów XIX-wiecznej architektury przemysłowej, dzięki której Łódź jest nazywana „polskim Manchesterem”. Świadkami przeszłości są także zabytkowe wille i kamienice, zachwycające ciekawymi rozwiązaniami architektonicznymi i bogatą dekoracją.

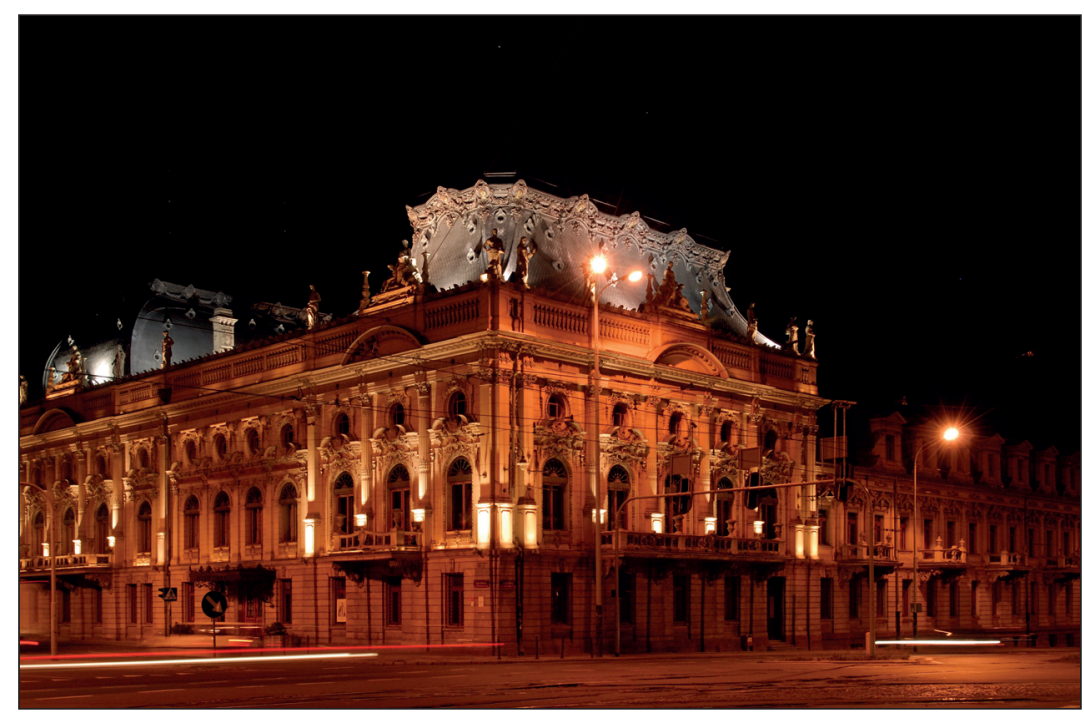

Fot. 2. Pałac Poznańskich (aut. P. Buczek)

\section{Eódź Czterech Kultur}

Tożsamość dynamicznie rozwijającego się miasta budowali nie tylko Polacy, ale także ludność napływowa, którą stanowili przede wszystkim Niemcy, Żydzi i Rosjanie. Ślady tego niepowtarzalnego dziedzictwa możemy podziwiać do dzisiaj w postaci licznych zabytków architektury sakralnej oraz nekropolii. Do dziś sąsiadują ze sobą kamienice wzniesione przez niemieckich czy żydowskich właścicieli. Podziwiać możemy cerkwie, kościół ewangelicko-augsburski (fot. 3) i synagogę. Na największym w Europie cmentarzu żydowskim, wśród tysięcy macew, znajdują się mauzolea łódzkich fabrykantów, nagrobki rabinów 
i cadyków oraz pole gettowe ofiar eksterminacji Żydów przez Niemców w okresie II wojny światowej. Pamięć mieszkańców Litzmannstadt Getto upamiętnia pomnik zagłady - Stacja Radegast.

$\mathrm{Na}$ Starym Cmentarzu w części katolickiej, prawosławnej i ewangelickiej spoczywają łódzcy przemysłowcy, artyści, naukowcy, aktorzy.

W tradycje Łodzi wielokulturowej i wielowyznaniowej wpisuje się Festiwal Łódź Czterech Kultur. Przedstawienia i koncerty artystów polskich, niemieckich, rosyjskich i żydowskich gromadzą co roku liczną publiczność.

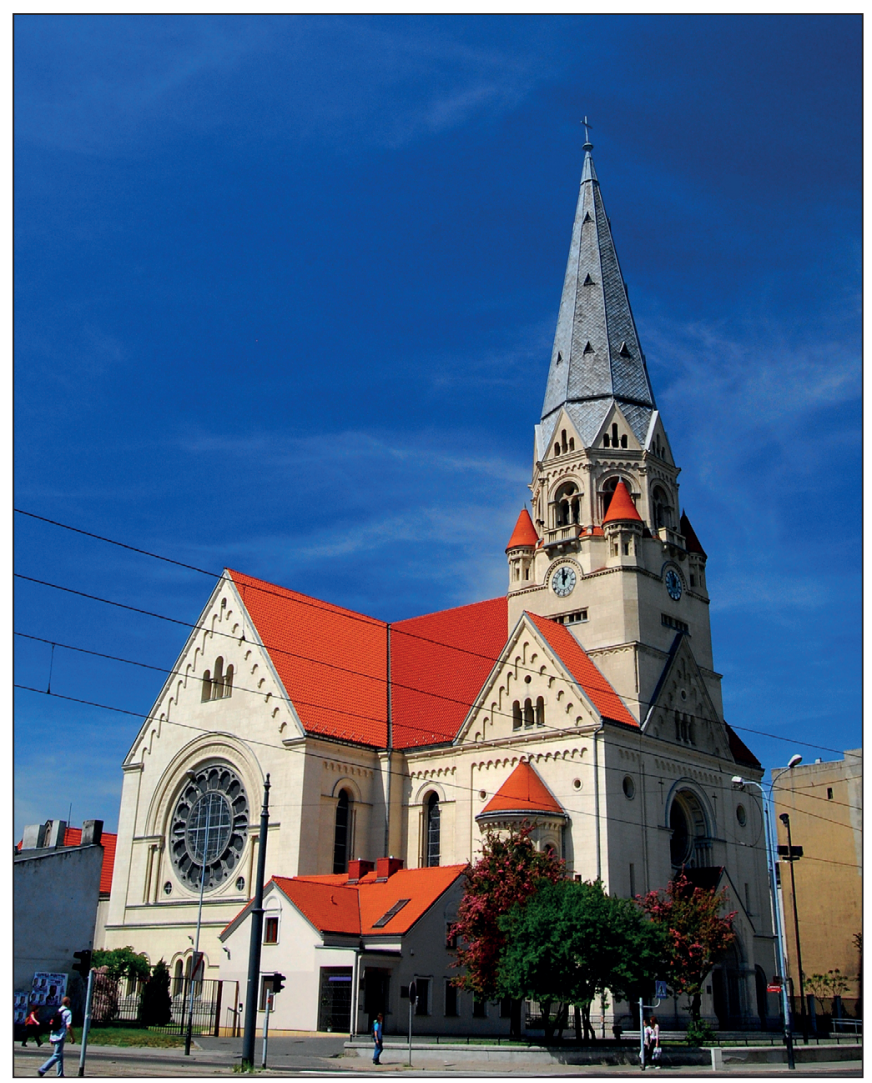

Fot. 3. Kościół ewangelicko-augsburski św. Mateusza (archiwum Urzędu Miasta Łodzi)

\section{Ulica Piotrkowska}

Niekwestionowaną wizytówką i sercem miasta jest ulica Piotrkowska - najdłuższy deptak w Polsce (fot. 4). Wzdłuż dawnego traktu komunikacyjnego rozwijała się zabudowa miasta. To tutaj łódzcy fabrykanci wznosili swoje kantory 
i składy towarów, banki oraz wielkomiejskie kamienice. Do dzisiaj ulica zachowała reprezentacyjny charakter i tętni życiem o każdej porze. W dzień odwiedzających przyciągają liczne sklepy, a wieczorem w pubach, klubach, restauracjach i kawiarniach koncentruje się życie kulturalno-rozrywkowe. W wielu z nich organizowane są koncerty na żywo oraz imprezy klubowe. Miłośnicy muzyki dance mogą przetańczyć całą noc w dyskotekach. W sezonie letnim do odpoczynku zachęcają kolorowe ogródki gastronomiczne. Po deptaku można przemieszczać się rikszą lub trambusem, który jest repliką zabytkowego tramwaju.

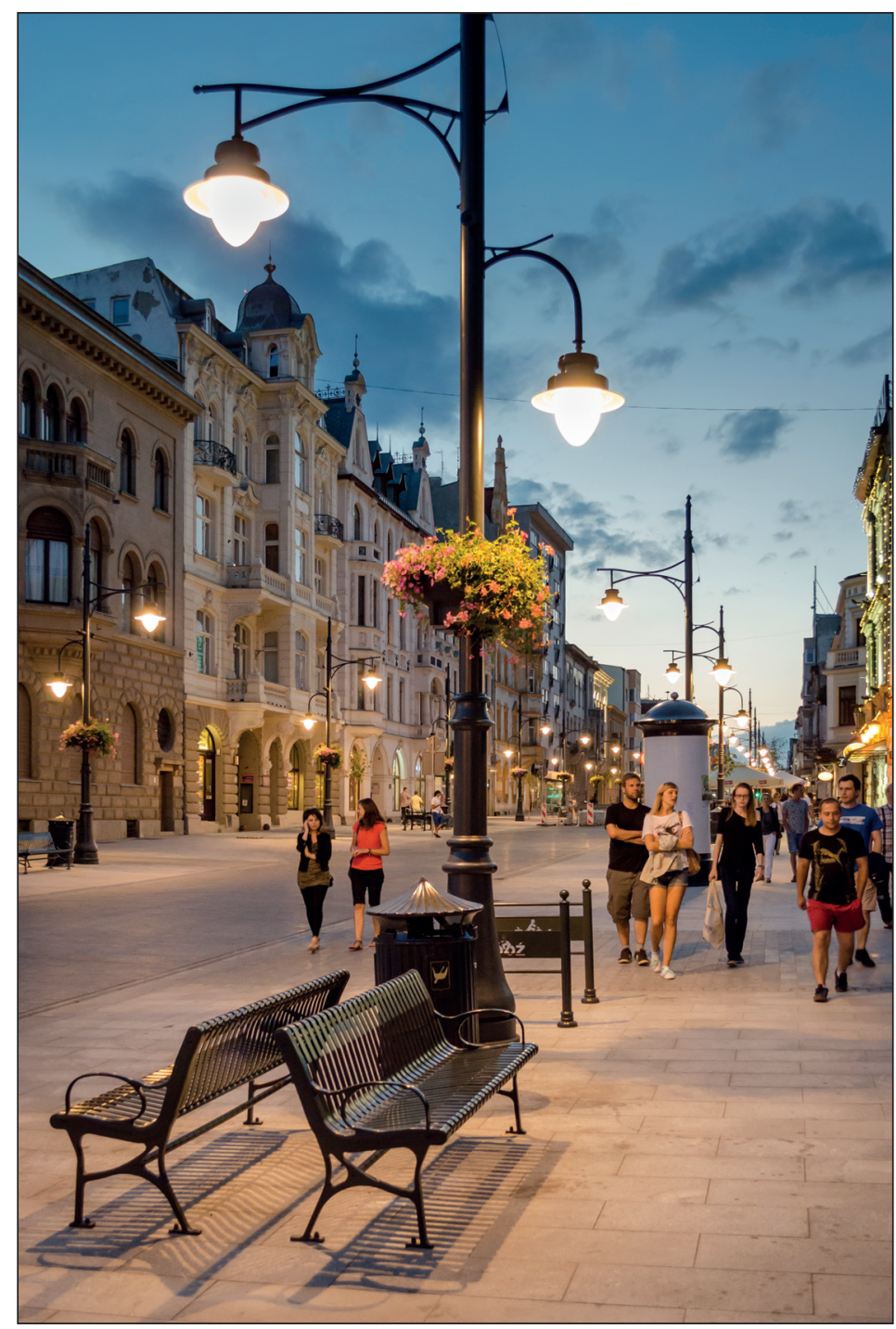

Fot. 4. Ulica Piotrkowska (aut. P. Wojtyczka) 


\section{Manufaktura}

Doskonałe możliwości połączenia zakupów z rozrywką daje Manufaktura - centrum kulturalno-rozrywkowo-handlowe, mieszczące się w zrewitalizowanym kompleksie fabrycznym z XIX wieku (fot. 5). Na powierzchni kilkunastu hektarów funkcjonują: galeria handlowa z markowymi sklepami i butikami, różnorodne lokale gastronomiczne, dyskoteka, ścianka wspinaczkowa, multiplex, luksusowy hotel i centrum kongresowe oraz cztery muzea: Muzeum Miasta Łodzi, Muzeum Sztuki ms², Muzeum Fabryki, Muzeum Nauki i Techniki Eksperymentarium, a także teatr. Centralne miejsce kompleksu zajmuje kilkuhektarowy rynek z fontannami - ulubione miejsce wypoczynku łodzian i turystów, tu odbywają się koncerty i festyny. Zimą rynek zmienia się w lodowisko, a latem w plażę. Będąc w Łodzi, koniecznie trzeba odwiedzić to miejsce.

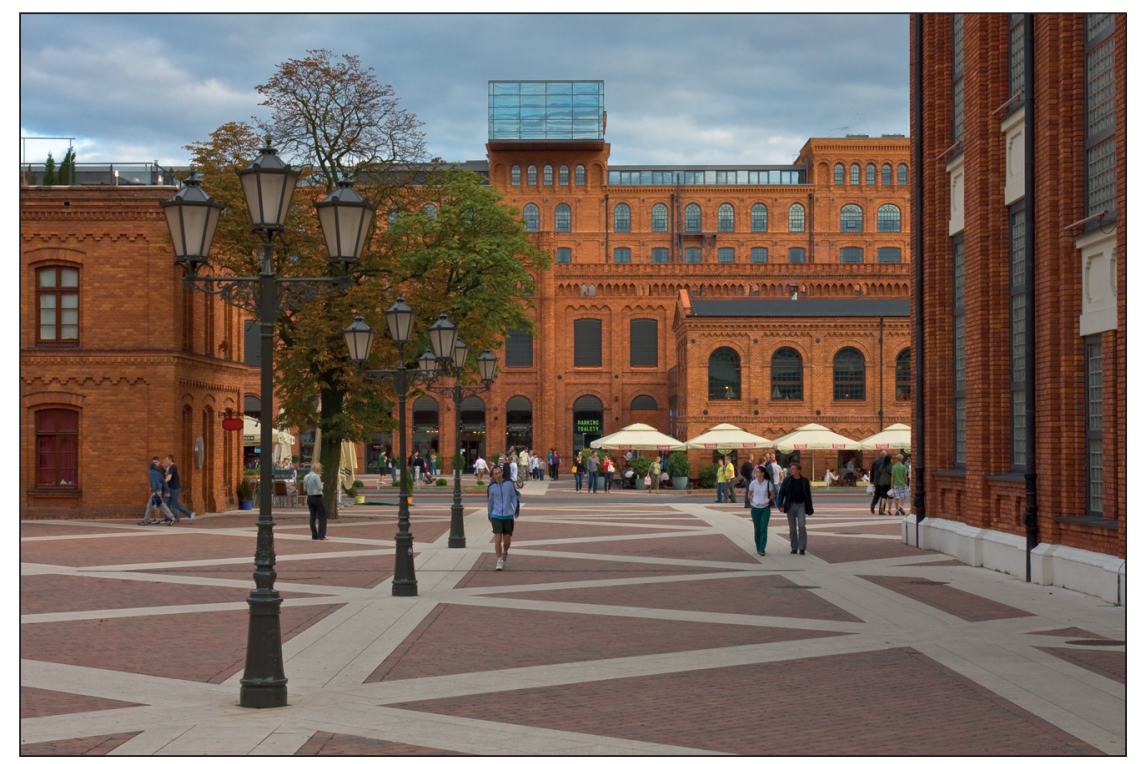

Fot. 5. Manufaktura (aut. P. Wojtyczka)

\section{Łódzkie muzea}

Wśród wielu placówek muzealnych znajdujących się w Łodzi kilka, ze względu na wielkość zbiorów i wartość kolekcji, zasługuje na szczególną uwagę. Niewątpliwie jest to Centralne Muzeum Włókiennictwa (fot. 6). Mieści się w klasycystycznym budynku fabrycznym L. Geyera i prezentuje historię rozwoju przemysłu w Łodzi oraz zabytkowe maszyny włókiennicze. Ponadto od lat gromadzona jest tutaj kolekcja współczesnej tkaniny artystycznej, 
a na organizowane Międzynarodowe Triennale Tkaniny przyjeżdżają artyści z całego świata. Ofertę muzeum wzbogaca Skansen Łódzkiej Architektury Drewnianej, eksponujący budynki z XIX wieku.

Cennymi zbiorami może się poszczycić Muzeum Sztuki (z oddziałem ms ${ }^{2}$ w Manufakturze), prezentujące największą w Polsce kolekcję sztuki awangardowej od kubizmu po surrealizm. Zobaczyć tu można prace takich sław, jak Max Ernst czy Pablo Picasso oraz artystów polskiej awangardy: Władysława Strzemińskiego, Katarzyny Kobro, Henryka Stażewskiego. Chcąc zapoznać się z urodą wnętrz fabrykanckich z przełomu XIX i XX wieku. koniecznie trzeba odwiedzić Pałac Herbsta (Oddział Muzeum Sztuki) oraz największy łódzki pałac fabrykancki rodziny Poznańskich (Muzeum Miasta Łodzi - z jedyną na świecie galerią im. Artura Rubinsteina). Nie sposób ominąć pałacu Scheiblera, w którego zabytkowych wnętrzach mieści się jedyne w Polsce Muzeum Kinematografii.

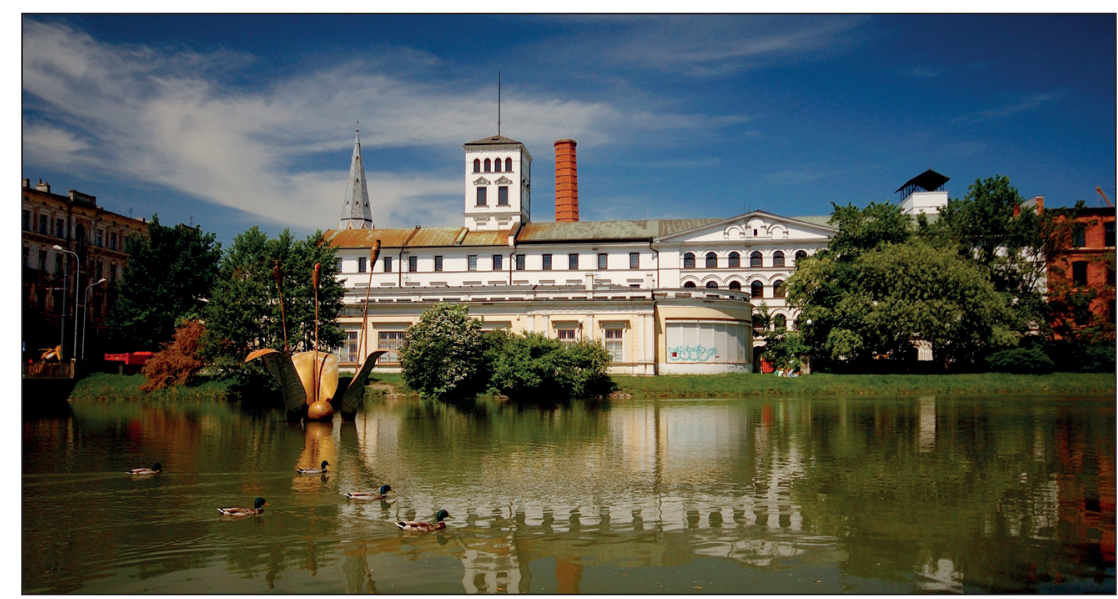

Fot. 6. Biała Fabryka - Centralne Muzeum Włókiennictwa (aut. M. Kawczyński)

\section{Hollyłódź}

Łódź od wielu lat uważana jest za stolicę polskiej kinematografii, a słynna łódzka szkoła filmowa wykształciła takie sławy, jak: K. Kieślowski, A. Wajda czy R. Polański. Na ulicy Piotrkowskiej w Alei Sław, wzorowanej na hollywoodzkiej Walk of Fame, znajdują się gwiazdy wybitnych osobowości polskiego kina. Od lat w mieście odbywa się wiele filmowych wydarzeń i festiwali. W Muzeum Animacji najmłodsi mogą obejrzeć lalki i fragmenty scenografii pochodzące z najciekawszych i najbardziej znanych filmów animowanych zrealizowanych w łódzkim studiu Se-ma-for. Są wśród nich legendarne dobranocki: Miś Uszatek, Przygody Misia Colargola, Mały pingwin Pik-Pok, Zaczarowany ołówek, a także arcydzieła, które wpisały się w kanon światowej kinematografii: 
Tango Zbigniewa Rybczyńskiego czy nagrodzony Oskarem w 2008 r. Piotruś $i$ wilk Suzie Templeton. W Muzeum Animacji Se-ma-for można również zobaczyć elementy planu filmowego i sprzętu wykorzystywanego do produkcji filmowej (fot. 7).

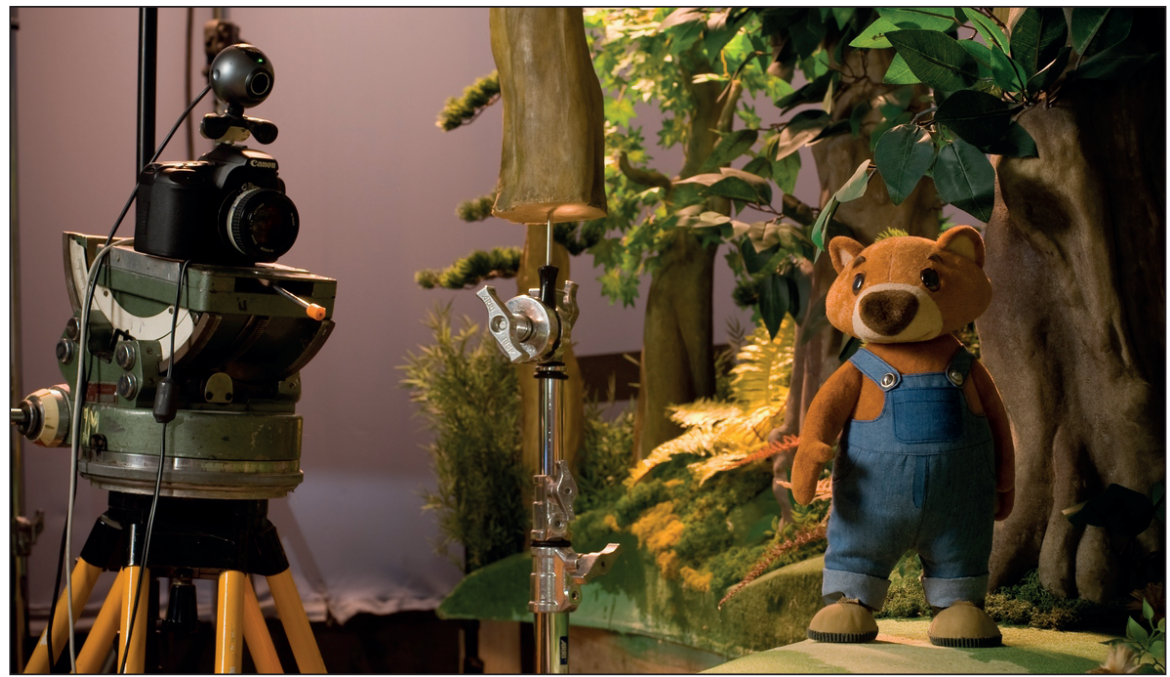

Fot. 7. Se-ma-for Muzeum Animacji (archiwum SMA)

\section{Lódź festiwalowa}

Łódź to bez wątpienia miasto festiwali. Kolejne edycje znakomitych imprez gromadzą wybitnych gości, a także turystów z kraju, Europy i świata. To właśnie w Łodzi zorganizowany był pierwszy w Polsce FashionPhilosophy Fashion Week Poland. Równie znanym jest Łódź Design Festiwal, ukazujący nowości i zmiany w świecie wzornictwa. Z myślą o twórcach i miłośnikach komiksu powstał ponad 20 lat temu Międzynarodowy Festiwal Komiksu i Gier (fot. 8). W stulecie powstania animacji lalkowej swoją premierę miał Se-ma-for Film Festiwal - pierwszy w Europie festiwal animowanych filmów lalkowych. Na równie wysokim poziomie plasują się imprezy muzyczne. Założeniem Międzynarodowego Konkursu i Festiwalu Indywidualności Muzycznych im. Aleksandra Tansmana jest prezentacja muzyków, kompozytorów z kraju i zagranicy o znaczącym i uznanym dorobku. Podczas Międzynarodowego Festiwalu Producentów Muzycznych Soundedit można posłuchać wyjątkowych koncertów, wziąć udział w warsztatach muzycznych, spotkać się z producentami i wykonawcami. Jedynym w Polsce i jednym z niewielu na świecie jest Międzynarodowy Festiwal Solistów Lalkarzy, którego głównym celem jest pokazanie wszelkich odmian sztuki królujących na lalkarskich scenach świata, a także propagowanie 
różnorodnych, indywidualnych form animacyjnych. Popularyzację i prezentację osiągnięć naukowych, zachęcenie młodych do pogłębiania wiedzy oraz integrację środowiska naukowego ma na celu Festiwal Nauki, Techniki i Sztuki. Jest to niepowtarzalna okazja do prezentacji osiągnięć naukowych na taką skalę i w tak atrakcyjny sposób.

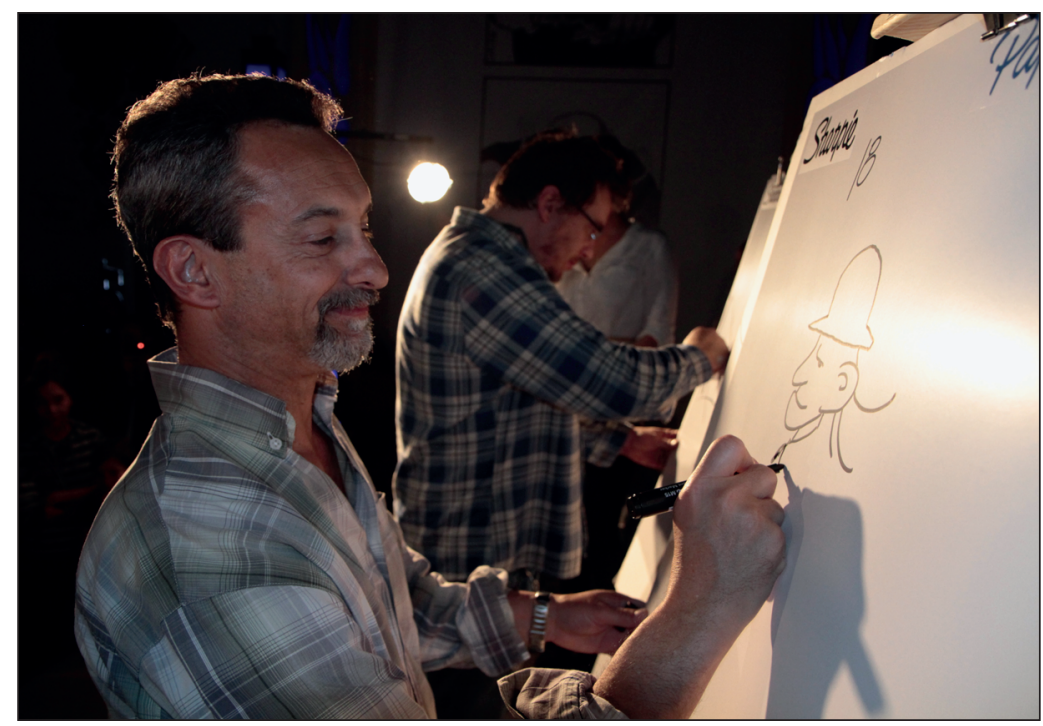

Fot. 8. Międzynarodowy Festiwal Komiksu i Gier (archiwum MFKiG)

\section{Lódzkie murale}

Wielkoformatowe graffiti, które wrosły już w pejzaż miasta, znane i podziwiane są nie tylko w kraju, ale też w szerokim świecie. Wybitni reprezentanci malarstwa wielkoformatowego zarówno z Polski, jak i z zagranicy tworzą murale w publicznej przestrzeni Łodzi. Prace malowane bezpośrednio na elewacjach kamienic powstają podczas festiwalu Galeria Urban Forms - zaliczonego przez „Graffiti Art Magazine” (prestiżowy francuski magazyn prezentujący współczesną sztukę miejską) do pięciu najważniejszych street-artowych festiwali na świecie (fot. 9).

Docelowo, na przestrzeni kilku lat powstanie miejska galeria, licząca kilkadziesiąt eksponatów, którą będzie można zwiedzić pieszo w ciągu paru godzin. Głównym celem projektu jest zmiana wizerunku Łodzi i znaczna poprawa jej codziennej estetyki tak, aby Łódź jako miasto było w przyszłości na całym świecie kojarzone z wartościową, nowatorską sztuką umieszczoną w przestrzeni publicznej. Wielkoformatowe obrazy stały się wizytówką miasta, a cała Galeria Murali jest jedną z wielu atrakcji turystycznych. 


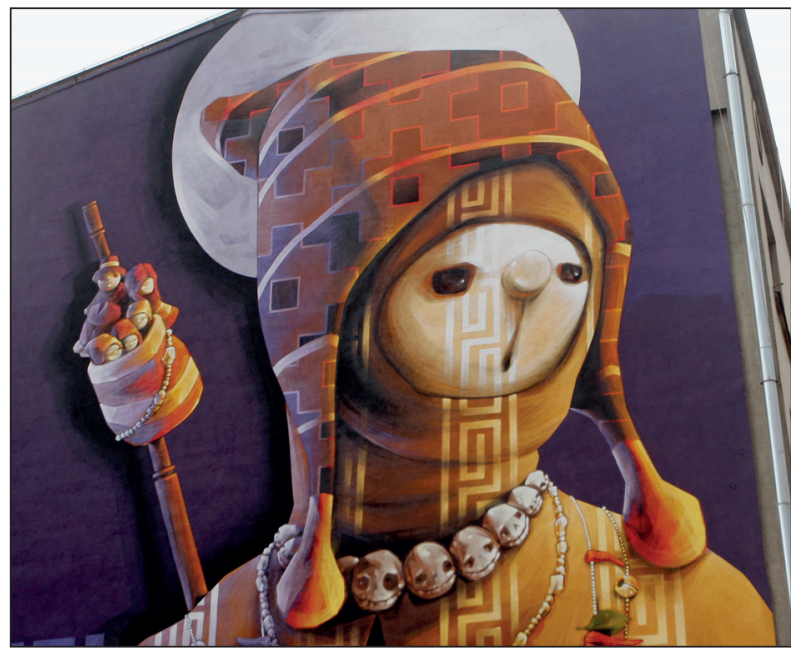

Fot. 9. Mural autorstwa Inti (archiwum Urzędu Miasta Łodzi)

\section{Lódź offowa}

Łódź jest miastem kreatywnych działań, a ulica Piotrkowska jest ich zagłębiem. Podwórko starej fabryki Ramischa przy ul. Piotrkowskiej 138/140 to miejsce, którego siła polega na potencjale ludzi mających zapał i chęci do podejmowania kreatywnych działań na wielu płaszczyznach. OFF Piotrkowska (fot. 10) aktywizuje łodzian, prowadząc szeroko pojęte działania kulturalne. Projekt skupia muzyków, artystów, designerów, animatorów kultury, projektantów mody i innych twórców szeroko pojętej kultury offowej. Dawne mury fabryki są miejscem rozwoju kultury, sztuki i kreatywnego biznesu. Powstała tu przestrzeń dla oryginalnych klubokawiarni, klubów, ekskluzywnych butików, pracowni projektantów mody i designerów, wystaw i koncertów.

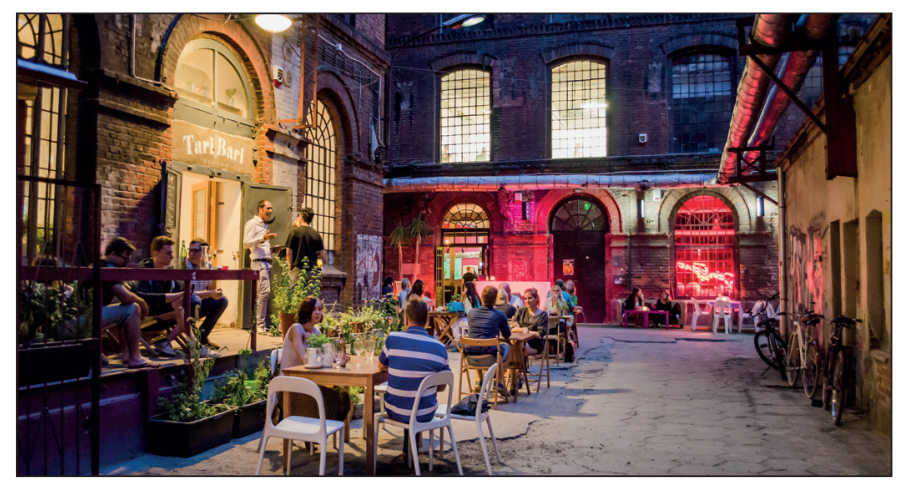

Fot. 10. OFF Piotrkowska (aut. P. Wojtyczka) 


\section{Nowe Centrum Lodzi}

Fabryczne kominy nad miastem nie dymią od lat. Łódź buduje swój nowoczesny wizerunek. Łódź, w której pomysłów na nowe oblicze nigdy nie brakowało, dziś ponownie jest o krok od radykalnej transformacji. Przykładem może być największy projekt rewitalizacyjny w Europie, czyli budowa Nowego Centrum Łodzi. Ten śmiały plan będzie urbanistycznym wehikułem czasu, w którym historia i nowoczesność przenikają się, tworząc jednolitą substancję miejską - ikonę na kulturalnej i inwestycyjnej mapie Europy.

$\mathrm{Na}$ NCŁ składać się będą trzy strefy. Pierwsza - z nowym, podziemnym dworcem Łódź Fabryczna połączonym z infrastrukturą komunikacyjną miasta. Nad dworcem stworzony będzie rynek, łączący NCŁ z ulicą Piotrkowską. Dominantami przestrzennymi staną się wyjątkowe obiekty: Brama Miasta, budynki zrewitalizowanej elektrociepłowni EC-1 (fot. 11) oraz Centrum Kongresowe, które będą otoczone obiektami Specjalnej Strefy Kultury.

W drugiej strefie będą realizowane przedsięwzięcia komercyjne, natomiast strefa trzecia stanowi obszar gęstej zabudowy historycznej z przełomu XIX i XX wieku, wymagający intensywnej modernizacji.

W ramach projektu „Rewitalizacja EC-1 i jej adaptacji na cele kulturalno-artystyczne" zostanie utworzona nowa przestrzeń publiczna. W zespole EC-1 Wschód znajdzie się m.in. Centrum Sztuki Filmowej, a zespół EC-1 Zachód będzie zaadaptowany na interaktywne Centrum Nauki i Techniki.

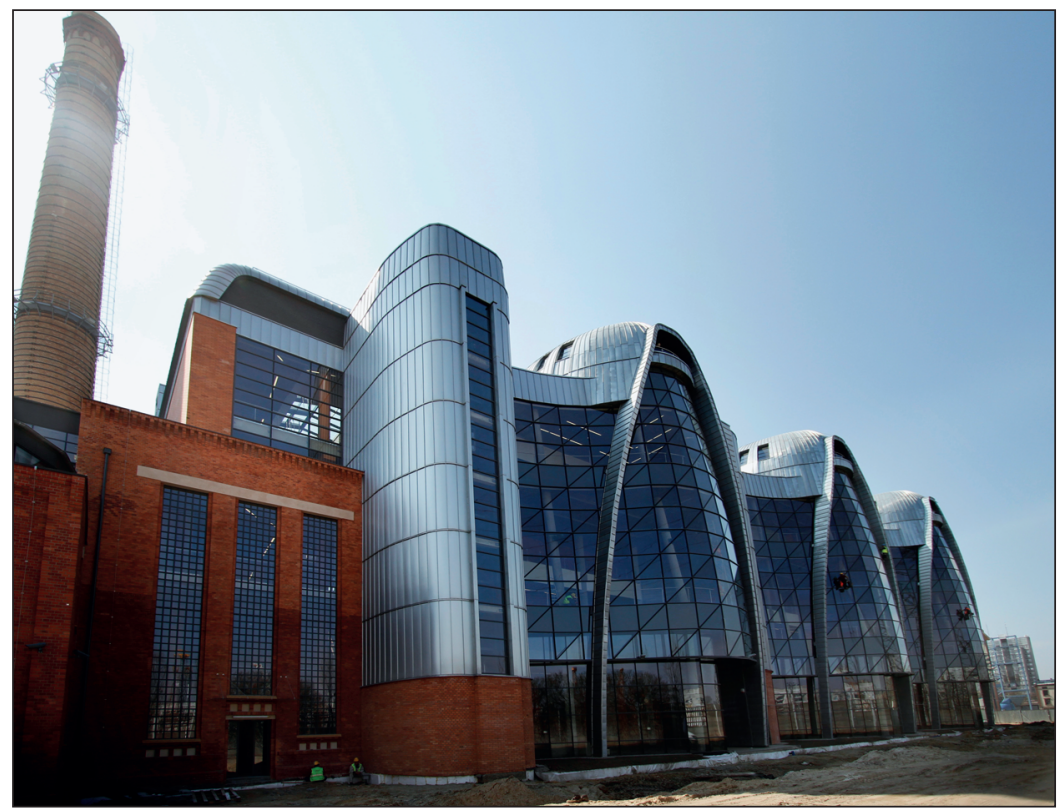

Fot. 11. EC-1 (archiwum Urzędu Miasta Łodzi) 